\title{
The Role of Line Managers and Practice of Strategic Human Resource Management: A Study Based on Sri Lankan Listed Companies
}

\author{
Thuduwage Lasanthika Sajeevanie \\ Department of Human Resource Management, University of Sri Jayewardenepura, Sri Lanka
}

\begin{abstract}
Every manager in an organization is responsible for achieving the goals and objectives of the organization. Similarly, managing human resource function is also a responsibility of every manager in an organization. Organizations exist for a variety of purposes. Some produce goods for local or overseas consumption while others provide necessary services for profit or community benefit. In pursuit of their objectives, all organizations rely on the availability and effectiveness of several kinds of resources, which can be divided into finance, technology, and people. Some organizations emphasize their financial resources others rely on the quality of their employees, their human resources. Regardless of the particular resource emphasis in industry, human resource is usually the key ingredient for organizational success. The purpose of this research is to study the devolvement of line managers in Human Resource Management (HRM) activities in the Sri Lankan context. To achieve the objectives of this research the researcher adopted the quantitative approach. The research strategy of the study was the survey method. For the empirical study, all the elements of the population were considered. The research findings of the study fill the empirical knowledge gap in the Sri Lankan context concerning the practice of Strategic Human Resource Management (SHRM). The findings of this study revealed that there is a significant relationship between the line manager's involvement in HRM activities and the practice of SHRM. This can be a guide for Sri Lankan organizations to increase the effectiveness of the Practice of SHRM to achieve organizational effectiveness.
\end{abstract}

Keywords: The role of Line Managers, Strategic Human Resource Management, Sri Lankan Context

\section{INTRODUCTION}

$\mathrm{E}$ mployees are one of the most important resources in any organization. Today organizations face a highly competitive situation. Hence, HR plays a major role in the eventual success or failure of any strategic business plan. The role of line managers in HR activities has received increasing scholarly attention in recent years and as heightened by Kehoe and Han (2020) this role was first recognized by HR scholars over 20 years ago. The practice of SHRM is mainly dependent on three factors; coherence, integration, and devolvement of HRM activities to line managers. Budhwar (2000) has identified the main feature of the practice of SHRM as the practices of integration of HRM into the corporate strategy and devolvement of responsibility of HRM to line managers'. Line managers are often the source of employees' most direct experience with an organization's HR practices, yet their critical role in the process of Human Resource (HR) practice delivery is often overlooked (Kehoe and Han, 2020, p. 111). According to the existing literature, there is an empirical knowledge gap in the Sri Lankan context in respect of the practice of SHRM (Sajeevanie and Opatha 2007). Relationship between Human Resource Manager related factors and practice of Strategic Human Resource Management in Sri Lankan Listed Firms. Sri Lankan Journal of Human Resource Management, 1, 71-87.

The purpose of this research is to study the involvement of line managers in HR activities in the Sri Lankan context. The study attempted to answer the following research questions:

- What are the HRM Competencies of Line Managers of the organizations under the study?

- Do the HRM competency of line managers affect the practice of SHRM?

- From the above research questions the researcher attempt to achieve the following research objectives:

- To describe the nature of the HRM competencies of line managers of the organizations under the study.

- To determine the effect of the HRM competencies of line managers of the organizations under the study on the practice of SHRM.

The research findings of the study fill the empirical knowledge gap in the Sri Lankan context concerning the practice of SHRM. Besides, this can be a guide for Sri Lankan top-level managers to increase the effectiveness of SHRM practice to achieve organizational effectiveness.

\section{RESEARCH FRAMEWORK}

HRM Competence of managers is self - assessed of manager's knowledge, skills, and abilities in respect of Human Resource Management, (Opatha and Ismail, 2002). Selmer and Chiu (2004) note a set of core HR competencies, which consist of leadership style, management intuition, functional abilities, and personal attributes. For this study, the working definition of HRM Competency of Line managers is "perceived level of manager's knowledge and skills in respect of Human Resource Management". 
As all managers despite their fields of specialization have subordinates to be managed, they have to deal with human resource management matters (Opatha and Ismail). All managers regardless of their functional area their position in the hierarchy and the size of the firm for which they work must deal effectively with HR issues because those issues are at the heart of being a good manager. According to him, every manager is a human resource manager. Like most HR activities, strategic HR planning will be of little value unless line managers are actively involved. Unfortunately, top management (including HR professionals) sometimes tends to see strategic planning as its domain, with line managers merely responsible for implementation. For HR strategy to be effective, line managers at all levels must buy into it. If they do not it is likely to fail. According to Mejia et al., (2003) like most HR activities, Strategic Human Resource Management practice will be of little value unless line managers are actively involved. HR devolution refers to the delegation of the responsibility for implementing HR practices to line managers outside the HR function. Many scholars have identified the positive impact of this on employee and organizational outcomes (Kehoe and Han, 2020. Zupan and Kase (2005) pointed out that the HR competencies of line managers are significant for the practice of SHRM. According to Change and Huang (2005), the line manager's participation in HRM, activities are potential influences on SHRM implementation. Hence, the poor HRM competency of other managers will affect the practice of SHRM. To examine this, the researcher suggested the following hypothesis:

HRM competency of line managers of the organization has a positive relationship with the practice of SHRM.

To operationalized the variable of HRM competency of Line managers, there were 11 dimensions; Human Resource Planning, Recruitment, and Selection, Orientation, Training, Appraising Job performance, Pay Management, Rewarding, Health and Safety, Managing Discipline, Grievance Handling, and Union Relations.

\section{METHODOLOGY}

\subsection{Research Design}

The type of this research is explanatory and since the researcher interference was minimal, the study was conducted in the natural environment. Therefore, the study was not conducted in any contrived or artificial setting. It was done in a purely non-contrived setting. Since for the study data were collected within a particular period this was a cross-sectional study. For this study, the unit of analysis was individual i.e. Head of the Human Resource Management in Sri Lankan listed companies. A survey method was used for the data collection of this study. Since the study was dependent on primary data, a questionnaire was used to collect data.

\subsection{Population and sample}

The list of the population was obtained from the handbook of the Colombo Stock Exchange. The Colombo Stock Exchange is a company liaison by the Securities and Exchange Commission to operate as a Stock Exchange in Sri Lanka. The Exchange has 242 companies listed with a market capitalization of approximately 262 billion rupees. A Company must minimum standards of quality, size, operations, and disclosure, and sufficient investor interest to be permitted to be listed on the Exchange. For this study, the population refers to all listed companies in Sri Lanka. Also, all the elements of the population were considered for the survey. Hence, no sample was involved in this research.

This study was purely based on primary data, which were collected through a survey. Since the unit of analysis of this study was Head of Human Resource Management, the data were collected by mailing a questionnaire with a self-address envelope.

\subsection{Validity and Reliability}

Validity tests how well an instrument that is developed measures the particular concept it is supposed to measure (Sekaran, 2003). Reliability is how well the instrument consistently and stably measures whatever the concept it measures (Sekaran, 2003). The content validity of the questionnaire of this study was ensured since the measure included an adequate and representative set of items that tap the concepts. Inter-item consistency reliability is a test of the consistency of the respondent's answer to all the items in a measure. The most popular test of inter-item consistency reliability is Cronbach's coefficient alpha, which was used to test the inter-item reliability of the instrument. Pearson correlation was used to identify the test-retest reliability. The content validity of the instrument was ensured by the conceptualization and operationalization of the variables in the literature.

\section{RESULTS}

Since there were 11, questions to measure the variable of HRM competency of the Line Managers the scores were assigned ranging from one to five.

Table 1 Level of HRM Competency of Line Managers

\begin{tabular}{|c|c|c|}
\hline Level & Frequency & Percentage \\
\hline 1- Very Low & 0 & 0 \\
\hline 2- Low & 4 & 2.5 \\
\hline 3-Moderate & 44 & 27.5 \\
\hline 4- High & 61 & 37.9 \\
\hline 5- V. High & 15 & 9.3 \\
\hline
\end{tabular}

As indicated by table 1 only $2.5 \%$ of the organizations had low HRM competency of line managers. None of the organizations was included under the category of "Very Poor". 27.3\% of the organization's Line Managers HRM competency was "Moderate" level. Only a few organizations (9.3\%) had a "Very High" level of HRM competency of Line Managers. The majority was under the category of "High". 
The Null hypothesis of the study was HRM competency of line managers of the organization does not have a positive relationship with the practice of SHRM. Pearson's correlation was used to test the null hypothesis. Pearson Correlation Coefficient between the two variables is 0.227 suggesting a high positive relationship between these two variables.

Table 2 Competency of Line Managers and Practice of Strategic Human Resource Management

\begin{tabular}{|c|c|c|}
\hline & $\begin{array}{c}\text { SHRM } \\
\text { Practice }\end{array}$ & $\begin{array}{c}\text { Competency } \\
\text { Of line } \\
\text { managers }\end{array}$ \\
\hline $\begin{array}{c}\text { SHRM P Corr } \\
\text { Practice Sig(1 } \\
\text { tailed) } \\
\text { N }\end{array}$ & $\begin{array}{c}1 \\
\cdot \\
137\end{array}$ & $\begin{array}{c}.227^{* *} \\
.009 \\
110\end{array}$ \\
\hline $\begin{array}{c}\text { Competency P C } \\
\text { of line Managers } \\
\text { Sig }(1 \text {-tailed }) \\
\text { N }\end{array}$ & $\begin{array}{l}.227^{* *} \\
.009 \\
110\end{array}$ & $\begin{array}{c}1 \\
\cdot \\
127\end{array}$ \\
\hline
\end{tabular}

Since results show (Table 2) that the P-value is less than 0.01, $(0.009<0.01)$ there is a positive relationship between these two variables. Therefore, the correlation is significant at the 0.01 level (1- tailed).

Therefore, there is statistical evidence to reject the null hypothesis that the HRM competency of line managers of the organization has no positive relationship with the practice of SHRM. Hence, the data supported the hypothesis that the HRM competency of line managers of the organization has a positive relationship with the practice of SHRM.

These findings support to prove that there is a relationship between line managers' HRM competency and Practice of SHRM. Similarly, Line managers' HRM competency affected the devolvement of line managers in HRM activities.

\section{CONCLUSION AND RECOMMENDATIONS}

This study has attempted to further develop the area of SHRM. It contributes to HRM theory by empirically testing the level of the key concept of devolvement in Sri Lanka. Within its limitations, the study has achieved the set objectives and opened avenues for future research. Therefore, conducting an SHRM study in the Sri Lankan context helps to meet the shortage of empirical work in the field in Sri Lanka. Hence, the HR Professionals, top management, and other concerned parties (line and staff managers) should understand that HRM is not only a responsibility of Human Resource Managers/Heads. All involved practices have their role to play in managing human resources effectively.

Every line manager should improve their HRM competencies. Besides, the findings of this study emphasize all other courses on management other than HRM specialized courses should address this issue. Hence, it can be recommended that all professional and academic courses should cover at least basic concepts of Human Resource Management. Then, while Human Resource Management courses can produce HR Professionals and all other professionals also having basic knowledge of HRM. Then it will be a support to practice SHRM in organizations.

\section{REFERENCES}

[1] Budhwar, P.S. (2000). Strategic Integration and Devolvement of Human Resource Management in the UK Manufacturing Sector, British Journal of Management, 11, 285-302.

[2] Change, W.A., and Huang, T. C. (2005). Relationship between strategic human resource management and firm performance: A contingency perspective, International Journal of Manpower, 26(5), 434-449.

[3] Kehoe, R.R., and Han, J.H. (2020). An expanded conceptualization of Line Managers' Involvement in Human Resource Management. Journal of Applied Psychology, 105(2), 111-129.

[4] Mejia, L.G.M., Balkin, D.B., and Cardy, R.L. (2003). Managing Human Resource, $\left(3^{\text {rd }}\right.$ ed). Pushp Print Services, Delhi.

[5] Opatha, H.H.D.N.P., and Ismail, Z.B., (2002). An n Empirical Investigation of Management - Related Factors Contributing to Labor-Management Relationship in Manufacturing Firms in Sir Lanka. NMMS Journal, January- June, 74-85.

[6] Sajeevanie, T.L., and Opatha, H.H.D.N.P. (2007). Relationship between Human Resource Manager related factors and practice of Strategic Human Resource Management in Sri Lankan Listed Firms. Sri Lankan Journal of Human Resource Management, 1, $71-87$.

[7] Sekaran, U., (2003) Research Method for Business: A skillbuilding approach. (4th ed.). Jonn Wiley \& Sons, Inc., New York.

[8] Selmer, J., and Chiu, R., (2004). Required Human Resource Competencies in the future: A Framework for developing HR Executives in Hong Kong, Journal of Management, 39, 324-336.

[9] Zupan, N., and Kase, (2005). Strategic human resource management in European transition economies: building a conceptual model on the case of Slovenia, International Journal of Human Resource Management, 16(6), 882 -902. 